\title{
Patriarchy Canonization: Comparing Women's Political Participation in Matrilineal and Patrilineal Orders in Sumatra, Indonesia.
}

\author{
Erond Litno Damanik*
}

Department of Anthropology, Faculty of Social Sciences, Universitas Negeri Medan, Indonesia

Received: August 12, 2021; Reviewed: August 24, 2021; Accepted: September 12, 2021

\begin{abstract}
The purpose of this study is to describe a recent comparison of women's political participation based on empirical evidence on the matrilineal and patrilineal orders in West and North Sumatra, respectively. This study was motivated by the low involvement of women in politics in the 2014 and 2019 general elections. The study offers specific insights into kinship order as political allegiance. This is qualitative research carried out using a pragmatic methodological approach with academic discussions directed at the relationship between kinship and political participation. The results showed that the canonization of Islamic patriarchy in the matrilineal order impacts involution and exclusive women in the domestic arena. Meanwhile, the canonization of Christian patriarchy in the patrilineal order impacts devolution and inclusive women in politics. Therefore, based on this empirical evidence, it is concluded that the kinship system is not a relevant political allegiance.
\end{abstract}

Keywords: Canonization; Patriarchy; Participation; Matrilineal; Patrilineal.

How to Cite: Damanik, E.L. (2021). Patriarchy Canonization: Comparing Women's Political Participation in Matrilineal and Patrilineal Orders in Sumatra, Indonesia. JPPUMA: Jurnal Ilmu Pemerintahan dan Sosial Politik UMA (Journal of Governance and Political Social UMA), 9 (2): $207-222$

*Corresponding author:

E-mail: eronddamanik@unimed.ac.id

ISSN 2549-1660 (Print)

ISSN 2550-1305 (Online) 


\section{INTRODUCTION}

In the last decade, one of the contemporary political realities in Indonesia is the small participation of women in politics, such as in becoming members of the legislative and executive. The 1999 decentralization law provided a great opportunity for the involvement of women in politics. Subsequently, implementing the $30 \%$ gender quota in 2003 also opened wider opportunities for them to participate in politics. However, their political participation has not increased. Rather, it has declined. For instance, in 2019, approximately $8.23 \%$ of Indonesian women participated in politics was only $8.23 \%$, and the gender quota has never been achieved since the 1999 decentralization law. The fundamental problem is why women's participation is relatively slow?

Preliminary studies have been carried out to determine the state factors influencing political participation. However, studies on the contribution of kinship order to political involvement are still minimal. Therefore, this study offers insights on kinship as political allegiance by specifically assessing the canonization of patriarchy through religious beliefs on kinship order that impact the inaction of political participation. Academic discussions are directed at the relationship of the kinship system with political allegiance for women in politics.

This study is relatively new and motivated by the low participation of women in politics based on the 2014 and 2019 general elections. It focuses on determining the matrilineal and patrilineal orders of the West and North Sumatra provinces, respectively. Despite concentrating on two provinces, this study is a general representation of Indonesia to determine the reasons for the decline in women's participation in politics. Furthermore, except for West Sumatra, which is matrilineal, the most common trend of kinship systems is patrilineal.
The canonization of patriarchy through religious belief is a systematic mechanism for involving women in the domestic arena. Therefore, this study proposes that women's mobility in politics is not only influenced by the state but also associated with their capability to undermine patriarchy. Although affirmative policies can increase women's participation, there are always efforts to marginalize them. This means that not all social units enthusiastically welcome affirmative policies due to women's mentality, nature, household, childcare, and even workload as politicians. These reasons seek to limit women's power in politics wrapped in the canonization of patriarchy through religious beliefs.

This study assesses the matrilineal and patrilineal orders in West and North Sumatra based on five considerations; (1) women's participation in politics increases and decreases in the patrilineal and matrilineal orders, respectively, (2) the characteristic of West Sumatra tends to be homogeneous and monocultural, Minangkabau and Islamic. Meanwhile, in North Sumatra, it is plural and multicultural, Angkola, Karo, Pakpak, Mandailing, Nias, Simalungun, and Toba, with Protestant, Catholic, and Muslim, (3) North Sumatra reflects the confederation of migrants. At the same time, West Sumatra is homogeneous, (4) the entities in the two provinces reflect an inclusive and aggressive ethnic group, and (5) the modernization of women in West Sumatra was influenced by colonialism, while in North Sumatra, it was influenced by colonialism as well as German and Dutch Christian Missions. This study is different from previous studies that emphasize the kinship system as political allegiance.

The essence of the study and feminism movement is equality, following (1) recognizing all rights and obligations, (2) formal education and wage employment, and (3) the right to elect and be elected (O'Brien, 2009; Gamble, 2006). However, the right to elect and be elected contributes to the first two points because there is no other 
mechanism to create equality in all aspects except through gender mainstreaming. Equality does not depend on a high income or a rich country; rather, men and women feel the same opportunities (Labani, Kaehler \& De Dios-Ruiz, 2009).

The study of feminism in various countries is focused on three important points; (1) the deconstruction of enlightenment impact of patriarchy in the U.K., (2) reproduction, parenting, sexual violence, sexuality, and domesticity, and (3) role over all aspects of life (Hill, 2003). The first two studies emphasized that the personal is political and departs from sociocultural norms (Norris \& Inglehart, 2003; Krook, 2014).

Contemporary feminism studies are carried out through a multidimensional approach. All studies are based on crucial problems caused by subordination, education, poverty, sexual harassment, and rape (Skelton, Francis \& Smulyan, 2008; Mitra, 2018). Furthermore, Blackburn (2009) emphasized the state's role in removing subordination. Dow and Wood (2009) stated that women could fill public spaces. Women are the source of enlightenment (van Bemmelen, 2018). Psychologically, there are no contrasting differences between men and women (Ryan \& Branscombe, 2013).

The climax of the feminism movement was the Seneca Falls Convention, the elimination of gender discrimination in 1848 (Gamble, 2006). However, the struggle to gain political access, whether elected or elected, was achieved in 1918. Politics is a representation of gender (Philips, 2003). However, only $23.3 \%$ of women hold parliamentary in the world (Kumar, 2017). Until the 21st century, women's participation in politics faced several challenges; hence, they were underrepresented and removed from decisionmaking at all levels.

Low participation triggers affirmative policies through gender quotas, sensitivity, and mainstreaming. Internationally, the gender quota with critical numbers of $30 \%$ has the opportunity to increase women's electability through general election institutions, closed list systems proportional and bureaucracy (Inter-Parliamentary Union [IPU], 2012; Ballington \& Karam, 2005; International IDEA, 2016).

In Indonesia, the gender quota is stipulated through Law number 8 of 2012 on Legislative General Elections, and Law number 2 of 2008 on Political Parties intended to achieve three main points; (1) the existence of regulations on women's political participation, (2) improving the quality of female candidates, and (3) changing the paradigm for women. Even though they are still discriminatory, the gender quota is a mechanism to increase women's political attention.

There are numerous gaps when comparing women's political participation in various countries. For example, there is a significant increase in the involvement of women in Western Europe and the United States due to five influencing factors; (1) the electoral system, (2) quotas, (3) time to elect, (4) higher education and wage employment, and (5) state development (Kantola, 2009). More specifically, in the monarchy in Western Europe, the position of the queen influences and pushes women into politics (Kumar, 2017).

Furthermore, other countries, such as Chile, Finland, Germany, Liberia, Ukraine, Argentina, India, Australia, and Indonesia, have inaugurated their first female executives. For example, Angela Merkel is the only female leader in the Group of Eight (G8), NATO, executives in the European Union, and German chancellors (Elise, 2008; Mushaben, 2018). In Indonesia, Megawati, chairman of the Indonesian Democratic Party of Struggle (PDIP), is the only female executive since the country gained independence 78 years ago.

Gender quotas motivate women to opt for legislative positions in Sri Lanka (Iwanaga, 2008). Meanwhile, in Taiwan, gender quotas promote women in 
parliament and are effective agents of change. In the Philippines, women in the legislature have increased significantly, although they are less effective as change agents (Veneracion-Rallonza, 2008). Apart from gender quotas, found other factors to promote women's involvement. For instance, in India, British colonialism, which instilled an ideology of equality, undermined social caste and encouraged women to participate in politics (Jones, 2021).

In the 15 to 18 centuries, women's participation in Myanmar was influenced by matriarchal traditions and routines (Tran, 2018). Compared to men, Myanmar women have higher performance, promoting their political involvement (Egreteau, 2019). In Japan, Thailand, Taiwan, and even the Philippines, their participation is influenced by the rise of the middle class (Croissant \& Lorenz, 2018). In Egypt, Cambodia, and Pakistan, women are marginalized from politics (Iwanaga, 2008). found Similar attributes in Saudi Arabia, Bangladesh, Afghanistan, Syria, Iraq, Iran, Egypt, Libya, and Morocco, where the patriarchy tradition is integrated with Islamic patriarchy and marginalize woman in politics (Croissant \& Lorenz, 2018). In China, the low participation rate is due to a lack of selfconfidence and male determination of social structure (Howell, 2006).

The two most popular women politicians in Indonesia are Megawati and Puan Maharani, and they belong to PDIP. Megawati, the presidential regime from 2001-2004, inspired women to enter politics (Robinson \& Bessell, 2002). However, the contemporary democratic movement led to nondemocratic pluralism debating gender quotas (Aspinall \& Mietzner, 2019). Furthermore, Islam has helped limit women's involvement in politics (Bylesjoe \& Seda, 2006; Henley \& Davidson, 2008). After the Megawati Soekarno Putri regime, women's participation continued to decline.

Political fragmentation is irrelevant to women's participation in the 21st century. According to F. Benda-Beckmann and $\mathrm{K}$.
Benda-Beckmann (2006) illustrated the triangular phenomenon between custom, Islam, and the state that marginalizes women in politics. Furthermore, Blackburn (2009) stated that women's discourse is more directed at the domestic sector. Women are declared weak and not violent in politics (Sari, 2020; Fatimah, 2012). Multiparty fragmentation creates multiple interpretations for the position of women in politics (Shair-Rosenfield, 2012; Fossati, 2019; Menchik, 2017; Latief \& Nashir, 2020). According to Sukri and Timo (2020) and Damanik (2020), regional autonomy through the issuance of discriminatory regulations also worsens women's participation in politics. In West Sumatra, Aceh, Banten, Palembang, South Sulawesi and South Kalimantan, politics is forbidden to women (Damanik, 2020). Ironically, Banten, led by a female executive, issued gender-based discriminatory limitations. Although Aceh has a history of female sultans, it is historical with political marginalization (Reid, 2005). The legislative women are increasing in North Sumatra, although their development is relatively slow. However, in the last ten years (20102020), many Indonesian women have become suicide bombers (Damanik \& Ndona, 2020; Damanik, 2020; Croissant \& Lorenz, 2018).

There are seven contemporary problems concerning women in Indonesia; (1) low access to productive resources, (2) education for the poor, (3) health services in villages, (4) gender mainstreaming of institutions, (5) low participation in decision making, (6) high violence, and (7) international migrant rights (Country Gender Assessment [CGA], 2006). This study assesses the matrilineal and patrilineal orders as political allegiance. The practical importance of kinship systems is to assert rights, obligations, privileges, status, and succession. It reflects the principle of complementary action and is focused on groups and not relatives. 
The principle of authority following the patrilineal system describes the roles and functions of men as husbands and resources compared to matrilineal (Blackwood, 2000). Furthermore, Narayan (2018) stated that the matrilineal system is the relationships reckoned by women or groups adhering to a kinship system in which ancestral descent is traced through maternal instead of paternal lines. The low involvement of women in politics is paradoxical with a matrilineal order (Selinaswati, 2014). The patrilineal principle is the relationships reckoned through the father, which are emphasized to the organization of family relationships in societies by lines of descent from a person's male ancestors (O'Brien, 2009; Teik, 1972).

The increasing participation of women in politics in North Sumatra is due to the flexibility of the patrilineal order and the varying beliefs regarding their roles and positions. Women in politics are not solely due to gender quotas; rather, it is the right of every citizen. Based on the above descriptions, this study compares matrilineal and patrilineal orders to determine a crucial problem for the inaction of women's participation in politics.

\section{RESEARCH METHODS}

This civilizational political study aimed to determine the development of conceptual and practical tools for women's political participation in the $21^{\text {st }}$ century (Schutt, 2016). The study was originally planned for January-August 2020; however, due to the Covid-19 pandemic, it was postponed to August 2020-March 2021. Furthermore, this study was qualitatively conducted using a pragmatic methodological approach (Creswell, 2014). Qualitative is intended to explore the canonization of patriarchy based on experiences in realistic situations as outlined in narrative text. The pragmatic methodological approach follows a mixedmethods design designed to determine the root of the problem in a causal-functional manner (Greene \& Hall, 2010). The experience described is a narrative to affirm or reject the canonization of patriarchy (Denzin \& Lincoln, 2005).

The kinship system analysed in this study is matrilineal in the Minangkabau entity in West Sumatra and patrilineal in the Angkola, Karo, Pakpak, Mandailing, Melayu, Nias, Simalungun, and Toba in North Sumatra. The exploration of the kinship system is intended to determine four main points; (1) the tendency of political allegiance based on matrilineal and patrilineal orders, (2) the indoctrination mechanism of patriarchy and religious beliefs, (3) factors that affirm or undermine indoctrination, and (4) discuss gender sensitivity to politics.

There are three kinds of informants; (1) female politicians, (2) community leaders, and (3) voters. Female politicians are selected based on information from the General Election Commission (KPU) and political parties. Community leaders are obtained from ethnic, religious, or clan associations, while voters are selected through suggestions from community leaders. Female politicians are 184 legislative and six executives elected in the 2019 general election whose identities are obtained from KPU. Email correspondence received 97, while community leaders and voters are determined on a snowball basis.

General information regarding the kinship system is analyzed through written sources, while the phenomenon of patriarchy canonization is obtained through virtual focus group discussions. The virtual FGD was held on February 17, 2021, by inviting 51 participants from both regions. All participants are female politicians, community leaders, and voters determined based on ethnic, religious, educational, and occupational considerations. Interviewed Several female politicians with questions on their personal experiences formulated on Google forms, email, or WhatsApp. All information and especially informants' names are kept confidential to avoid public misperception. 
All data were manually collected, was found in the region. The participation of tabulated, coded, verbally transcribed, and women in the political arena in 2019 was conceptualized. Validation and reduction of only $7 \%$, which decreased from $8.37 \%$ in subjectivity were carried out by comparing 2014.

subjects. Furthermore, crosschecks between subjects were carried out via email and cellphone. All data were elaborated and analyzed in a narrative-interpretive manner based on the subject's practical experience. At the end of the study, there are a concluding remark, theoretical and empirical contributions, and follow-up.

\section{RESULTS AND DISCUSSION}

West Sumatra consists of 12 regencies and seven cities with a population of 5.57 million consisting of 2.80 million women, according to a 2020 census. In 2014, 585 legislative members in 19 administrative regions consisted of 49 women, which decreased to 41 in 2019. Currently, Padang City has seven legislative women, while Solok and South Mentawai have none. The provincial parliament level in 2019 comprised four women, which decreased from 8 in 2014. In the same year, West Sumatra had a female representative in the Indonesian parliament, and after that, none

North Sumatra consists of 26 regencies and eight cities with 15.03 million, consisting of 5.57 million women from a 2020 census. Furthermore, in 2019, there were 1,205 legislative members in 34 administrative regions composed of 1,062 men and 143 women, which increased from 121 in 2014. Women's participation decreased at the provincial level from 14 legislative members in 2014 to 13 in 2019. Meanwhile, at least two women are found as legislative members at the regency and city parliament levels.

In 2019, Karo, Asahan, and Labuhanbatu regencies had ten female legislative and female executive-led regions in North Sumatra, three in the Indonesian parliament. Furthermore, women's participation in politics increased to $11.86 \%$, from the previous $10.04 \%$ obtained five years ago. Table 1 shows women's involvement in the political and public arenas in the two provinces.

Table 1: Women's Involvement in The Political and Public Arenas

\begin{tabular}{llcccc}
\hline No & Components of the political and public arenas & \multicolumn{2}{c}{ North Sumatra } & \multicolumn{2}{c}{ West Sumatra } \\
\cline { 3 - 6 } & & $\mathbf{2 0 1 4}$ & $\mathbf{2 0 1 9}$ & $\mathbf{2 0 1 4}$ & $\mathbf{2 0 1 9}$ \\
\hline 1 & Elected local legislative & 121 & 143 & 49 & 41 \\
2 & Elected local executives & 4 & 6 & - & - \\
3 & Mainboard of political parties & 73 & 89 & 22 & 11 \\
4 & Local legislative candidates & 201 & 264 & 67 & 85 \\
5 & Local executive candidates & 12 & 16 & 2 & 2 \\
6 & Echelon Officials and Regional Owned Enterprises (ROEs) & 187 & 223 & 89 & 83 \\
\hline Source: & Fieldwork, 2020 & & &
\end{tabular}

Based on the field findings above, women's participation in politics in the two provinces is still below the $30 \%$ gender quota. In 2019, women's participation was only $7 \%$ in West Sumatra and $11.86 \%$ in North Sumatra, with an average of $9.43 \%$. This percentage is similar to the $8.23 \%$ recorded at the national level. As a note, point 6 in Table 1 above shows the prevailing gender mainstreaming in Indonesia. Women gain positions in every hierarchy of government and Regional Owned Enterprises (ROEs) even though the percentage is lower than men.

In 2020, Indonesia's population consisted 135,821,768 men and $132,761,248$ women. Based on this data, the involvement of women in the political arena needs to be greater than men. However, there were only 97 women out of 572 members of the Indonesian parliament (DPR-RI) in 2014, which increased to 118 
in 2019. Furthermore, in 2019, North Sumatra had three female legislative in the Indonesian parliament, while eight other provinces, including West Sumatra, did not have any.

Based on the data above, three general trends in women's participation in the two provinces are noted as follows: (1) participation in North Sumatra is higher than in West Sumatra, (2) women's participation in West Sumatra tends to decrease, and (3) women's participation in North Sumatra tends to increase. In other words, women's participation in matrilineal entities shows a decrease compared to patrilineal.

Before further exploration, women's participation in the two provinces are summarized in the following six general views: (1) affirming the political arena as a channel of participation for social and cultural change, (2) political involvement is the right of all citizens regardless of gender, (3) having interests, desires and ambitions to become politicians, both legislative and executive, (4) having the ability to balance the domestic and public arenas, (5) opposing the nature and stigma of incompetent, weak, gentle, or lackluster women, and (6) opposing patriarchy domination of the political arena.

The six general perceptions above have specific variants regarding women's participation in politics. Compared to Minangkabau and Mandailing, women from Angkola, Karo, Pakpak, Nias, Simalungun, and Toba are more flexible in the political arena. The patrilineal order of the six entities as Boru (family receiving girls), parsonduk (leaders in the kitchen), and parbulang (leaders in custom) inspire women to appear in the public arena.

Although the pattern is patrilineal, the social structure is triangular (tolu sahundulan) and pentagonal (lima saodoran), in which they are highly respected. Generally, women are not only considered the source of reproduction, kinship, and fertility; rather, they are also the blessing of life in all aspects. Households tend to collapse, assuming women are not wise. For example, in Simalungun and Toba, the death of a wife is the beginning of household destruction (toppas tataring).

The general trend, the patrilineal system, does not limit women's activities in all aspects. They are often seen as "heads of household," customary controllers, farm managers, church leaders, or peacemakers. Many women work as parking attendants, taxi drivers, and other public transportation systems, including online. In Simalungun, Karo, and Pakpak, a few men become babysitters when their wives work. In market centers, women are more active as traders (perengge-rengge). They have lost their husbands prefer to be widows and struggle on their own for economic stability and their children's education. Women also have a significant workload and responsibility in controlling the nuclear and extended family.

Based on observation, the number of women involved in Church activities is greater than men, illustrating the suffering of life and the blessings for each work. Furthermore, preaching in Church always promotes the equality of women and men. In other words, the patrilineal order tends to be flexible and tolerant of all women's activities. All these realities illustrate the involvement and resilience of women in all areas and large capital for their participation in politics. Based on this trend, it is not surprising that many women in North Sumatra are registered as administrators of political parties, legislature, and executive members.

The tendency of the six entities in North Sumatra is different in Minangkabau and Mandailing. In both these entities, the ideal space of women is in domestic activities. The domestic arena includes all jobs to support the household, such as farming, trading, or the state civil apparatus. In both entities, women have limited access to the political arena. The 
social reality in these two entities shows the responsibility of women to the household. The announcement of their position in the domestic arena is inflated through religious discourse where the leader is male.

The comparison between Mandailing and Minangkabau is explained as follows; (1) in the Mandailing entity, the patrilineal order positions women as subordinate. Socio-cultural barriers and religious patriarchy discourses are internalized in every woman. Gradually and continuously, the polarity was affirmed and assumed to be absolute truth. On the contrary, (2) in the Minangkabau entity, matrilineal order is expected to apply in the customs and village sectors. It is less ideal for the public arena with vague and ambiguous men's roles and functions. However, the patriarchy discourse was inflated through religion to eliminate the political element in the matrilineal order. Religious doctrines are systematically extended through meetings, agencies, associations, and local government regulations.

The position of Minangkabau women is a dilemma, with a matrilineal order on the one hand and trapped in Islamic patriarchy on the other. Patriarchy canonization weakens the political position of women. The matrilineal order is stated to only apply in every day and village work. Patriarchy discourse is inflated through discriminatory regional regulations, political campaigns, informal meetings, and daily communication. Halimah, on telephone communication on September 23, 2020, stated the following:

"For us Minangkabau women and those in West Sumatra, becoming a civil servant (PNS) is the highest goal. Through this route, our career paths can relatively fill the hierarchy of government. To avoid public scorn, we had to balance with the domestic through promotions. Outside of civil servants, we have difficulty filling public spaces, all of which are dominated by men. Despite our desire to join politics, we must postpone it for fear of being ridiculed to violating nature, customary norms, and especially religion."

History recorded religious and customs conflicts in West Sumatra, with the climax being the Padri movement, religious purification over customs domination. After this movement, the Minangkabau social philosophy received Islamic affirmation, adaik basandi syarak, or sharia-based customs (Selinaswati, 2007). As a result, all social orders affirm religious doctrine. Gradually, crushed the matrilineal system into the domestic space, and women were marginalized. These efforts have been successfully implemented since the 1970s. Furthermore, the Arab Spring further Islamized the matrilineal order in 1999. Subsequently, social philosophy and the spirit of decentralization are firmly integrated by creating discriminatory regulations on women.

The canonization of religious patriarchy eliminated the political elements of the matrilineal order. This reality has been strengthened by religiousbased political parties such as the Prosperous Justice Party (Partai Keadilan Sejahtera [PKS]) and the National Mandate Party (Partai Amanat Nasional [PAN]). In West Sumatra, both parties received the biggest votes in 2014 and 2019, although they failed to deliver women as legislative or executive (Pandiangan, 2017). Four legislative women at the provincial level in 2019 are cadres of nationalist parties such as PDIP, Gerindra, and Golkar. Nurcahyati, telephone communication, November 2, 2020, stated the following:

"The matrilineal order is totally irrelevant to our desire to become legislative. The increase in patriarchy discourse during general elections encouraged women to work hard to increase electability. This is because 
the matrilineal order is paradoxical to majority belief and limits their political access. All aspects, both customary, social, economic, cultural, and political, are packaged in a religious frame Adaik basandi syarak, and they are actually a serious problem for women."

The voters' segregation in the 2014 Presidential Election patterned grassroots based on nationalist and religious parties. Furthermore, political parties and religious-based associations simultaneously defined the 2014 policy as a way to gain sympathy. In 2019 , several regions, such as Aceh, South Sulawesi, Palembang, South Kalimantan, Banten, including West Sumatra, have confirmed Islam as their respective region and have openly become national opposition.

Historically, the women's movement in West Sumatra has been seen in the emergence of educated female figures, special women's schools, newspaper publications, and the formation of organizations. Some women fighters were Rasuna Said, Rohana Kudus, Siti Manggopoh, etc. However, after independence, none of the women figures was popular in West Sumatra. Before colonialism, organized education in a surau (mosque), a non-formal education system blended customary with Islam. In the colonial era, modern educational institutions emerged. Also, a special teacher training school was established for women. Islamic educational institutions also emerged. The dualism of education gave rise to intellectual dualism. In the end, the dualistic tendency of education creates conservative Islamic politicians.

In West Sumatra, three newspapers specifically for women were Soenting Melajoe, Asjraq, and Soeara Kaum Iboe Soematera. These three media reflect the existence and role of women amid a matrilineal order and encourage participation in national movements. The politics of the campaign reached its peak in the 1930s. Various political parties, schools, and professional organizations came together to gather strength against colonialism. However, they were all influenced by the Pan Middle East Islamism movement.

Based on the description above, this study finds three mechanisms of patriarchy canonization in the matrilineal order; (1) making patriarchy based on Islam the main reference. In this section, religious dogmas and trends in Islamic countries such as Egypt and Saudi Arabia are ideal references for strengthening male leadership, (2) affirming human nature and looking for women's weaknesses to push it into the domestic arena. In this section, the main references are giving birth, nurturing, being too cooperative, inability to work at night, and concentrating divided on the public and domestic, and (3) discussing patriarchy overall public channels such as education, newspapers, movement associations, and political parties through regular meetings, local regulations, government bureaucracy, campaign displays, and religious institutions.

The three patriarchy canonization mechanisms above marginalized women. The ratification of all these mechanisms is confirmed through religious discourse. As a result, the matrilineal order undergoes involution, namely the exclusivity of women in the domestic arena. The matrilineal charge only applies to customs and jobs in the village which are related to housekeeping. Women are only responsible for protecting inheritance such as rice fields, houses, livestock, and labor (Blackwood, 2001).

Religious patriarchy is a fundamental problem for women to participate in politics. The matrilineal order and politics are wrapped in religious patriarchy. Therefore, the women's position is very dilemma and contradictory. During decentralization, the general trend was that religion was packaged into a tool and 
used to determine obedience, polygamy, raise children, and manage the household. In the end, all educational institutions, women's movement associations, newspapers, and political parties are heavily influenced by Islam. The pervasiveness of Islam in all aspects of life affects women's participation. This explanation is relevant to Young's (1994) and Selinaswati's (2014) research regarding the contradiction of Islamic law with matrilineal customs.

Women's participation in patrilineal entities in North Sumatra is more enlightening compared to West Sumatra. The tendency of women to participate in politics is the influence of Christian religions. Due to the paradox with the patrilineal Mandailing entity, Islam has restricted women's access to politics. Historically, women in North Sumatra have significantly contributed to the struggle for equality, such as the Lopian Sinambela in North Tapanuli. During the independence era, Rohani Darus was the first female mayor in Tebingtinggi for two regimes spanning 1990-2000. Furthermore, Basyirah Lubis, Nurmina Siregar, and Terang Singarimbun, as Kartini, Perwari, and Wanita Karo Halls initiators, are pioneers and activists of women in North Sumatra. Mamat Munthe is known as the first female customary leader in North Sumatra.

The existence of organizations that opposed colonialism and simultaneously promoted women. The Karo Association in 1919, the Batak Youth in 1920, the Gotongroyong Batak in 1922, the Advisory Committee in Simalungun in 1928, the Simalungun Association in 1933, the Batak Christian Union in 1934, and the Deli Islam Children in 1939 contributed to the women's movement in North Sumatra. This record shows that the women's movement in North Sumatra is not a present reality; rather, it was a pioneer in the past. Mery, personal communication, October 27, 2020, stated the following:
"Political women are a natural desire of every citizen. Despite being a woman, I have never been inhabited by my parents from choosing politics as a career channel. In my opinion, politics is not the world of men alone because women have the right to enter politics, which has been proven today. I did not violate the customary order as a politician and a mother. I need the roles of other people such as baby nurses, household assistants, personal drivers, etc. Therefore, whether you like it or not, we must do carry out these activities to succeed in politics."

Mery is not the first to become a legislative member on the political stage in North Sumatra. A number of names have even been recorded as members of the local legislature and executive such as Susanti Dewayani, the mayor of Pematangsiantar, Corry Sebayang, the regent in Karo, and Atika Azmi Utammi Nasution, the deputy regent at Mandailing Natal. Previously, Nurhajizah Marpaung, deputy governor of North Sumatra, Nurhayati Damanik, deputy regent in Simalungun, Sabrina, and South Labupanbatu, and Nelly had run for deputy mayor of Medan. However, compared to West Sumatra, women in North Sumatra are freer to participate in politics.

Apart from education, the situation of plural ethnicity and multiculturalism contributed to encouraging women to become politicians. Pasaribu, a political observer at the University of North Sumatra through personal communication, November 1, 2020, stated the following:

"Pluralism and multiculturalism encourage individuals to contest in all aspects of life, including politics. The reality in North Sumatra, based on the 2019 legislative elections, shows gender sensitivity. Apart from the education achieved, plural and multicultural setting prepared each individual to compete. Furthermore, 
the situation of ethnicity encourages the women's movement in North Sumatra to participate in politics."

The enlightenment of women in the six ethnicities in North Sumatra is inseparable from the colonial educational institutions and the German and Netherland Christian Mission by Rheinische Missiongesselschaf (RMG) and Netherlandsche Zendinggesselschaf (NZG). Education changes women's perceptions of patrilineal customs and reflects Western and Christian linearity in North Sumatra. Through education, gender ideology permeates men and women, thereby facilitating the discourse of equality, which is the main tool against discrimination and patriarchy canonization. Education motivated six women in Angkola to publish Borue Tapanoely, a women's newspaper in Sidempuan. Furthermore, it encouraged the publication of Perempuan Bergerak by Parada Harahap, a newspaper that reported women in Sibolga. Ani Idrus published Doenia Wanita in Medan, which reported on women.

In Laguboti, the RMG established the Madchen School, a special school for the woman. Meanwhile, in Karo, Botje set up a research center to train women to cultivate horticulture. In the end, education became the main tool to undermine the canonization of patriarchy, oppose patrilineal customs and change the mode of reproduction (van Bemmelen, 2018). In other words, education systematically influences religious and customary patriarchy to determine equality in social, cultural, economic, and political spaces (Heffner, 2020).

Before 1982, women were rarely found as leaders, officials, politicians, legislators, and executives. The patrilineal order was still being inflated according to religious and customary patriarchy, and despite their educational qualifications, limited their social mobility to the domestic arena. Women with degrees in theology, for example, were not accepted as pastors in tribal churches. However, in 1982, the Batak Protestant Christian Church (HKBP) received four female pastors. In 1984, Minaria Sumbayak, the first female theologian from the Simalungunese, an alumnus of the Jakarta Theological College in 1959, was accepted as a pastor. A similar phenomenon was followed by the Karo, Pakpak, Angkola, and Nias Churches. The acceptance of women as pastors is the pinnacle of equality amongst both genders in the Church.

After the Church received female pastors, it decorated almost all areas in North Sumatra with the presence of women. Klenke's (2007) exploration of Karo Christian Young women shows a desire to appear modern, ambitious, and refined. Furthermore, Klenke named Karo women farm controllers. According to Baiduri (2013), the economic reality of the Toba ethnic group allows the flexibility of the patrilineal order to exchange roles from domestic to public. This reality is seen in mothers' ability to control the traditional markets. For the Simalungunese, the position of the boru is a peacemaker for social and kinship conflicts (Damanik, 2021). According to Damanik (2020), women are resources that give life and blessings from the mother to the nuclear family, sanina, and stops in the community (boru). The parsonduk conception for married women describes an egalitarian leader (Saragih, Lolo, and Pranoto, 2019). Gradually, the affirmation of women as leaders in the Church became entry points in all areas.

The refusal of the 1982 patriarchy canonization was carried out through three mechanisms; (1) determining the weak point of patriarchy over the realities of life. At this stage, women's nature is opposed by men's work on rice fields, markets, customs, childcare, and kinship conflicts, (2) the deconstruction of patriarchy to determine equality. At this stage, the ideology of equality is found in cultural 
spaces, historical bases, formal education and theology, and (3) discourses women's involvement in all public and political arenas. At this stage, women are declared to have the capability to balance the domestic and public arenas. Based on the three mechanisms, patriarchy deconstruction causes devolution and inclusiveness of women in politics.

The beneficial interests of the kinship system are irrelevant as a means of asserting the rights, obligations, privileges, status, and succession of women's practical politics. The kinship system does not reflect the principle of complementary action between the domestic and political arenas. Patriarchy canonization tends to marginalize women's political roles. The reality found in West Sumatra is relevant to other areas that affirm the Islamic region, such as Aceh, South Kalimantan, South Sulawesi, Riau, Nusa Tenggara, Banten, etc. In this area, the patrilineal order was legitimized by Islamic patriarchy; therefore, women's participation declined.

Furthermore, the reality in North Sumatra is relevant to other areas such as Gorontalo, North Sulawesi, Bangka Belitung, Minahasa, Central Kalimantan, West Kalimantan, East Kalimantan and Maluku. In this area, the patrilineal and patriarchal order of Christianity is very open. Therefore, women are free to participate in politics. Apart from the customary domination in Papua, patrilineal at the same time due to unequal education thus, women still dominate in the domestic arena.

However, women's participation in politics is relatively difficult to develop. In a sense, the gender quota of $30 \%$ in Indonesia is rather difficult to realize due to the following five reasons; (1) canonization of religious patriarchy as a political tool in legislative and executive election events, (2) women's blockade of politics through discriminatory regulations in autonomous regions, (3) multiparty fragmentation which has an impact on the inconsistency of women's roles in politics, (4) capability to undermine the canonization of patriarchy for freedom over politics, and (5) determining socio-cultural barriers to certain entities.

Although the kinship system reaches out to relatives and groups, it is not effective as political allegiance. This research showed that the patriarchal canonization of Islam in a matrilineal order impacts involution and exclusive women in the domestic arena. Conversely, the canonization of the Christianity patriarchy in the patrilineal order impacts the devolution and inclusion of women in politics. Based on the explanation above, compared to the matrilineal order, women in the Christian patrilineal order are at liberty of opposing the narrative of patriarchy canonization.

The ability to undermine the canonization of patriarchy in a patrilineal order reflects the reality of life where men cannot fulfill their obligations as head of the household. The very high life demands oblige women to participate in all areas. In contrast, patriarchy canonization in matrilineal order tends to close women's political space. Even though men cannot fulfill their obligations as head of the household, religious doctrine tends to declare women in all situations. In the end, they tend to be obedient, resigned, and less enthusiastic in the political arena.

The kinship system is irrelevant as political allegiance. The kinship only applies to traditional societies where adherence to customary norms. Conversely, in modern society, this system is shackled by religion as a political tool. However, this is not quite right as civilizational politics, compared to the kinship system, generates a more meaningful social imagination capable of mobilizing entities for political purposes.

This study's theoretical and practical contributions are conducted by ending the patriarchal canonization of the social systems. Furthermore, women's political 
reality in North Sumatra is a blueprint for all women in Indonesia not surrender to patriarchy ideology. Political participation is intended to resolve real problems faced by women, such as inequality which is not merely a product of state institutions. Rather it is the capability to undermine the canonization of patriarchy.

\section{CONCLUSION}

In conclusion, the opportunities for women to develop careers in politics did not run smoothly and were hindered by the canonization of religious patriarchy over the kinship system. The religious patriarchy dogma where men because are considered absolute truth. Therefore, the political awareness that is formed relatively creates equality as dreamed by women. As long as the canonization of religious patriarchy is still being discussed and without women's efforts to undermine it, equality becomes impossible to implement.

Practical experience through this study shows that the canonization of patriarchy in the matrilineal order pushes women backstage through three mechanisms; (1) the doctrine of religious patriarchy as a political reference, (2) women's nature as a positioning mechanism in the domestic arena, and (3) dominating all public and political channels as the male arena. The canonization of religious patriarchy in the patrilineal order propelled women to the front stage; (1) discovering the weakness and lack of patriarchy ideology for all the realities of life, (2) equality in all arenas through religious and educational institutions, and (3) plunging into politics.

Therefore, this study concluded that the kinship system is not relevant as political allegiance based on empirical evidence. The canonization of religious patriarchy in the matrilineal order led to the involution and exclusion of women from politics. Conversely, the canonization of religious patriarchy in the patrilineal order led to devolution and the inclusion of women in politics. The reality of life in the matrilineal order creates proclamation, while in the patrilineal order, it makes flexibility; therefore, women appear independent and free in politics. This study recommends further research with a broader theme for each entity in Indonesia to explore the canonization of religious patriarchy in the social system. This recommendation is needed to determine a specific and comprehensive explanation, especially to increase women's participation while building a more egalitarian democratic order.

\section{ACKNOWLEDGMENTS}

The authors thankfully acknowledge all West and North Sumatra informants for their willingness to provide the data needed in this study. Also, recognize the Dean of Faculty of Social Sciences who supported this research.

\section{BIBLIOGRAPHY}

Aspinall, E. \& Mietzner, M. (2019). Southeast Asia's troubling elections: Nondemocratic pluralism in Indonesia. Journal of Democracy, 30(4), 104-118. https://doi.org/10.1353/jod. 2019.0055

Baiduri, R. (2013). Bukan sekedar untuk uang: Makna kerja perempuan pedagang Batak Toba (Inang-inang) di Kota Medan. PhD Thesis, Universitas Gadjah Mada, Indonesia.

Ballington, J, \& Karam, A. (2005). Woman in parliament: Beyond numbers. Stockholm: International Institute for Democracy and Electoral Assistance.

Benda-Beckmann, F., \& Benda-Beckman, K. (2006). Changing one is changing all: Dynamics in the Adat-Islam-State Triangle. The Journal of Legal Pluralism and Unofficial Law, 38(53-54), 239-270.

Blackburn, S. (2009). Woman and the state in modern Indonesia. Cambridge: Cambridge University Press.

Blackwood, E. (2000). Webs of Power: Women, kin, and community in a Sumatran Village. Rowman and Littlefield Publishers.

Blackwood, E. (2001). Representing women: the politics of Minangkabau Adat writings. The Journal of Asian Studies, 60(1), 125-149. https://doi.org/10.2307/2659507

Bylesjoe, C. \& Seda, F. (2006). Indonesia: The struggle for gender quotas in the world's largest Muslim Society. In D. Dahlerup (ed.). 
Erond Litno Damanik. Patriarchy Canonization: Comparing Women's Political Participation in Matrilineal

Women, quotas and politics (pp. 259-265). New York: Routledge.

CGA. (2006). Indonesia: Country gender assessment. Manila: Southeast Asia Regional Department, Regional and Sustainable Development Department, and Asian Development Bank.

Creswell, J.W. (2014). Research design: Qualitative, quantitative, and mixed methods approaches. Thousand Oaks, CA: Sage Publications

Croissant, A. \& Lorenz, P. (2018). Comparative politics of Southeast Asia: An introduction to governments and political regimes. Switzerland AG: Springer. https://doi.org/10.1007/978-3-31968182-5

Croissant, A. \& Lorenz, P. (eds.). (2018). Indonesia: Challenges of conflict and consensus in the Era of Reformasi. In Comparative politics of Southeast Asia: An introduction to governments and political regimes (pp. 71111). Switzerland AG: Springer, https://doi.org/10.1007/978-3-31968182-5

Damanik, E.L. (2021). Dispute resolution: Pentagonal relationships in the Simalungun ethnic group. Asia-Pacific Social Sciences Review, 21(1), 211-223

Damanik, E.L. (2020a). Identity-based administrative involution in Indonesia: How political actors and community figures do it? SAGE Open, 10(4), 1-13 https://doi.org/10.1177/2158244020974 015

Damanik, E.L. (2020b). The desire of power: Candidate ambiguity and incumbent monopoly in local leaders' election. Masyarakat, Kebudayaan dan Politik, 33(3), 286-298.

https://doi.org/10.20473/mkp.V33I32020 .286-298

Damanik, E.L. (2020c). Ethnicity situation and intolerant attitudes in multicultural societies in the Medan City. Humaniora, 32(1), 39-50. https://doi.org/10.22146/jh.v32i1.43918

Damanik, E.L. (2020d). Menegakkan kekerabatan: Struktur lima saodoran pada upacara perkawinan etnik Simalungun. Walasuji, 11(1), 1-28. https://doi.org/10.36869/wjsb.v11i1.67

Damanik, E.L. \& Ndona, Y. (2020). Revelation is a symbol: Anti-radicalism of pluri-religious communities according to Jaspers in the context of Indonesia. International Journal of Criminology and Sociology, 9, 587-603. https://doi.org/ 4409.2020.09.57
Denzin, N.K. \& Lincoln, I. (2005). The Sage Handbook of qualitative research. Thousand Oaks, CA: Sage Publications

Dow, B.J. \& Wood, J.T. (2009). The Sage Handbook of gender and communication. Thousand Oaks, CA: Sage Publications. https://doi.org/10.4135/9781412976053

Egreteau, R. (2019). Towards legislative institutionalisation? Emerging patterns of routinisation in Myanmar's Parliament. Journal of Current Southeast Asian Affairs, 38(3), 265-285. https://doi.org/10.1177/1868103419892 422

Elise, W.S. (2008). Chancellor Angela Merkel-A sign in hope or the exception that proves the rule. Politics \& Gender, 4(3), 485-496. https://doi.org/10.1017/S1743923X0800 0391

Fatimah, S. (2012). Gender dalam komunitas masyarakat Minangkabau; Teori, praktek dan ruang lingkup kajian. Kaafah: Journal of Gender Studies, 2(1), 11-24. https://doi.org/10.15548/jk.v2i1.37

Fossati, D. (2019). The resurgence of ideology in Indonesia: Political Islam, Aliran and political behaviour. Journal of Current Southeast Asian Affairs, 38(2), 119-148. https://doi.org/10.1177/1868103419868 400

Gamble, S. (2006). The Routledge companion to feminism and postfeminism. London: Routledge.

Greene, J.C. \& Hall, J.N. (2010). Dialectics and pragmatism: Being of consequence. In Tashakkori A and Teddlie C (eds). SAGE Handbook of mixed methods in social and behavioral research (pp. 119-143). Thousand Oaks, CA: Sage Publications, https://doi.org/10.4135/9781506335193. n5

Halimah. (2020). Telephone communication. September 23.

Heffner, R.W. (2020). Routledge Handbook of Contemporary Indonesia. London: Routledge.

Henley, H. \& Davidson, J.S. (2008). In the name of Adat: Regional perspectives on reform, tradition, and democracy in Indonesia. Modern Asian Studies, 42(4), 815-852. https://doi.org/10.1017/S0026749X0700 3083

Hill, L. (2003). The political gender gap: Australia, Britain and the United States. Policy and Society, 22(1), 69-96. https://doi.org/10.1016/S14494035(03)70014-9.

Howell, J. (2006). Women's political participation in China: in whose interest elections? 
Journal of Contemporary China, 15(4), 603619.

https://doi.org/10.1080/1067056060083 6614

International IDEA. (2018). A framework for developing internal gender policies for electoral management bodies. Stockholm: International Institute for Democracy and Electoral Assistance.

IPU. (2012). Advancement of women. Available at http://www.undp.org (accessed November $22,2020)$

Iwanaga, K. (2008). Women's political participation and representation in Asia: Obstacles and challenges. Copenhagen: NIAS Press

Jones, J. (2021). Acting upon our religion: Muslim women's movements and the remodeling of Islamic practice in India. Modern Asian Studies, 55(1), 40-74. https://doi.org/10.1017/S0026749X1900 043X

Kantola, J. (2003). Women's political representation in the European Union. Journal of Legislative Studies, 15(4), 379400.

Klenke, K. (2007). Prety woman: Beauty, modernity and morality in Brastagi, North Sumatera. Zeitschrift fur Ethnologie, 132, 209-239.

Krook, M.L. (2014). Electoral gender quotas: A conceptual analysis. Comparative Political Studies, $\quad 47(9)$, 1268-1293. https://doi.org/10.1177/0010414013495 359

Kumar, P. (2017). Participation of woman in politics: Worldwide experience. IOSR Journal of Humanities and Social Sciences, 22(2),

77-88. https://doi.org/10.9790/08372212067788

Labani, S., Kaehler, C.Z \& De Dios-Ruiz, P. (2009). Gender analysis of women's political participation in 7 Southeast Asian countries: Bangladesh, Cambodia, the Philippines, Indonesia, Sri Lanka, East Timor, and Vietnam, 2008-2009. Regional Gender Program in South-East Asia-Stage II.

Latief, H. \& Nashir, H. (2020). Local dynamics and global engagements of the Islamic modernist movement in contemporary Indonesia: The case of Muhammadiyah (2000-2020). Journal of Current Southeast Asian Affairs, 39(2), 290-309. https://doi.org/10.1177/1868103420910 514

Menchik, J. (2017). Islam and democracy in Indonesia: Tolerance without liberalism. Cambridge: Cambridge University Press.
Mery, S. (2020). Personal communication. October 27.

Mitra, A. (2018). Poverty, women, and dignity: Reflecting on the writings of Ashnapurna Devi. Asia-Pacific Social Science Review, 17(3), 155-159.

Mushaben, J.M. (2018). The reluctant feminist: Angela Merkel and the modernization of gender politics in Germany. Femina PoliticaZeitschrift fur feministische Politikwisssenschaft, 27(2), 83-95. https://doi.org/10.3224/feminapolitica.v2 $7 \mathrm{j} 2.07$.

Narayan, A. (2018). Matrilineal Society. Available https://www.britanica.com/topic/matrilin eal-society (accessed March 28, 2021)

Norris, P. and R. Inglehart. 2003. Rising the tide: Gender equality and cultural change around the world. New York: Cambridge University Press.

Nurcahyati. (2020). Telephone communication. November 2.

O'Brien, J. (2009). Encyclopedia of Gender and Society. Thousand Oaks, CA: Sage Publications.

Pandiangan, L.V. (2017). Perempuan politisi Minangkabau dalam dunia politik: Studi tentang alasan perempuan memaknai politik. Jurnal Politik Muda, 6(2), 148-155

Pasaribu, S.D. (2020). Personal communication. 01 November.

Philips, A. (2003). The politics of presence: The political representation of gender, ethnicity, and race. New York: Oxford University Press. https://doi.org/ 10.1093/0198294158.001.0001

Reid, A. (1998). Female roles in pre-colonial Southeast Asia. Modern Asian Studies, 22(3), 629-645. https://doi.org/10.1017/S0026749X0000 9720

Robinson, K. \& Bessell, S (eds.). (2002). Woman in Indonesia: Gender, equity, and development. Singapore: ISEAS.

Ryan, M. K., \& Branscombe, N.R. (2013). The SAGE Handbook of gender and psychology. London, UK: Sage Publications.

Saragih, J., Lolo, I., \& Pranoto, M. (2019). Allah sebagai parsonduk: Perempuan pemimpin dalam konteks Gereja Kristen Protestan Simalungun dan masyarakat Simalungun. Jurnal Abdiel: Khazanah Pemikiran Teologi, Pendidikan Agama Kristen dan Musik Gereja, $3(2)$, 47-68. https://doi.org/10.37368/ja.v3i2.107

Sari, S.K. (2020). Partisipasi perempuan di legislatif: Studi kasus DPRD Provinsi Sumatera Barat. Jurnal Sosiologi Andalas, $6(2)$, 
Erond Litno Damanik. Patriarchy Canonization: Comparing Women's Political Participation in Matrilineal

https://doi.org/10.25077/jsa.6.2.7078.2020

Selinaswati. (2014). Women in politics in matrilineal Society: A case study of West Sumatra, Indonesia. Ph.D. Thesis. Deakin University, Melbourne.

Selinaswati. (2007). A paradox of women representatives in a Muslim patriarchy and matrilineal Society in West Sumatra, Indonesia. Masters Thesis, University of Hawai'i, USA.

Schutt, R.K. (2016). Understanding the social world: Research Methods for the 21st century. Thousand Oaks, CA: Sage Publications

Shair-Rosenfield, S. (2012). The alternative incumbency effect: Electing women legislators in Indonesia. Electoral Studies, 31(3),

576-587. https://doi.org/10.1016/j.electstud.2012.0 5.002

Skelton, C., Francis, B., \& Smulyan, L. (2008). The SAGE Handbook of gender and education. London, UK: Sage Publications.

Sukri, T., \& Timo, D. (2020). Indigeneity and the state in Indonesia: The local turn in the dialectic of recognition. Journal of Current Southeast Asian Affairs, 39(2), 270-289. https://doi.org/10.1177/1868103420905 967

Teik, G.C. (1972). Why Indonesia's attempt at democracy in the Mid-1950s failed. Modern Asian Studies, 6(2), 225-244. https://doi.org/10.1017/S0026749X0001 5377

Tran, N.T. (2018). Familial properties: Gender, state, and Society in Early Modern Vietnam, 1463-1778. Honolulu: University of Hawai'i Press.

Van Bemmelen, S.T. (2018). Christianity, colonization, and gender relations in North Sumatra: A patrilineal society in flux. Leiden: Brill.

https://doi.org/10.1163/9789004345751

Veneracion-Rallonza, L. (2008). Women and the democracy project: A feminist take on women's political participation in the Philippines. In Iwanaga K (ed.). Women's political participation and representation in Asia: Obstacles and challenges (PP. 210-252) Copenhagen: NIAS Press.

Young, K. (1994). Islamic peasants and the state: The 1908 anti-tax rebellion in West Sumatra. New Haven: Yale University Southeast Asian Studies. 